\title{
UNIVERSITYOF
}

FORWARD

THINKING

WESTMINSTER用

WestminsterResearch

http://www.westminster.ac.uk/westminsterresearch

Citizenship and Inclusion: Rethinking the Analytical Category of

Noncitizenship

Tambakaki, P.

This is an Accepted Manuscript of an article published by Taylor \& Francis in Citizenship Studies, 19 (8), pp. 922-935. The final definitive version is available online:

https://dx.doi.org/10.1080/13621025.2015.1110285

(c) 2016 Taylor \& Francis

The WestminsterResearch online digital archive at the University of Westminster aims to make the research output of the University available to a wider audience. Copyright and Moral Rights remain with the authors and/or copyright owners.

Whilst further distribution of specific materials from within this archive is forbidden, you may freely distribute the URL of WestminsterResearch: ((http://westminsterresearch.wmin.ac.uk/)).

In case of abuse or copyright appearing without permission e-mail repository@westminster.ac.uk 


\title{
Paulina Tambakaki
}

Centre for the Study of Democracy

Department of Politics and International Relations

University of Westminster

32-38 Wells Street

London W1T 3UW

Tel.: 0207911 5000, ext. 68915

Email: tambakp@westminster.ac.uk

\section{Citizenship and Inclusion: Rethinking the Analytical Category of Noncitizenship}

\author{
Abstract \\ The paper problematises the category of noncitizenship. It traces its trajectory in \\ accounts of inclusive citizenship and argues that it is difficult to theorise it as a \\ distinct theoretical category outside of citizenship. To support this argument, the \\ paper distinguishes between a pluralist, political, and democratic variant of accounts \\ of inclusive citizenship; and it shows how they all end up reducing noncitizenship to a \\ journey to citizenship. To overcome this limit, the paper develops the idea of \\ subversive politicisation and suggests that injustices and inequalities can be \\ challenged without falling back on the vocabulary of citizenship.
}

Keywords: politicisation; exclusion; democracy; inclusive citizenship; political membership

\section{Introduction}


In the 'Decline of the Nation State and the End of the Rights of Man', a short chapter in The Origins of Totalitarianism, Hannah Arendt famously (and ambiguously) defined citizenship as the 'right to have rights' (Arendt, 1968, 296). Writing in the aftermath of the Holocaust and in the wake of the emergence of statelessness as a mass phenomenon, it was clear to Arendt that 'the loss of citizenship deprived people not only of protection, but also of all clearly established, officially recognised identity' $(1968,287)$. Does Arendt's emphasis on the primacy of citizenship still resonate today? The answer one gives to this question bears strongly on discussions of noncitizenship. Seeking to contribute to such discussions, this special issue on Theorising Noncitizenship exploits the ambivalence of the prefix non and enquires into the primacy of citizenship. In so doing, it carves out a space for noncitizenship as a distinct analytical category and invites contributors to reflect on its nature. The paper responds to this invitation. It problematises the distinctiveness of noncitizenship as an analytical category and explores its relationship with citizenship.

For the purposes of this paper, noncitizenship is taken to denote the condition of being where access to basic political rights is precarious and insecure. Noncitizenship is not the same as bare humanity, by which I mean a state of existence stripped of all rights and dependent on international human rights law (see Agamben, 1998). Although the conditions of existence that define the life of the noncitizen can be likened to conditions of bare humanity; the way I use the concept here steers away from such comparisons. This is because the underlying objective of the paper is to draw out and explore the political dimension of noncitizenship - the extent to which noncitizenship, as an umbrella term, successfully captures and challenges the exclusions, inequalities, injustices and naturalisations that accompany citizenship politics. Does noncitizenship transgress the relationship with citizenship, in line with the intentions of the special issue, or does it end up reproducing the relationship with citizenship that it seeks to overcome?

To addressing this question, the paper traces the trajectory of the concept of noncitizenship in accounts of inclusive citizenship and shows its floating nature. In particular, the paper distinguishes between a pluralist, political and democratic variant of accounts of inclusive citizenship; and highlights the shifts and turnings in the meaning of noncitizenship within such accounts. The paper argues that although all 
variants seek to interrogate and blur the binary citizen/noncitizen, they end up reinstating it. On the assumption that citizenship is the most valuable practice, the benchmark for evaluating - acknowledging and noticing -the demands raised by a variety of groups; the three variants cancel out noncitizenship as an analytical category. Noncitizenship becomes reduced to a journey to citizenship and, as such, it looses meaning and force. What are the implications of this loss? Although the paper suggests that it is possible to challenge exclusions, inequalities and injustices without references to noncitizenship, it does not altogether dismiss noncitizenship as a concept. Instead, the paper develops a comparison with the concept of politicisation and suggests that the first step to consolidating the analytical force of noncitizenship lies in the attenuation of the relationship with citizenship.

This argument develops in two sections. The first section starts with the examination of the concept of noncitizenship within accounts of inclusive citizenship, giving an idea of their limitations. The second section explores these limitations further through the comparison with the concept of politicisation.

\section{Citizenship, Inclusion and Noncitizenship.}

The category of noncitizenship confronts the theorist with a challenge. While it is apparent who the noncitizen is - anyone who does not have access to the formal rights of citizenship; the prefix non, that simultaneously affirms and negates citizenship, bears the marks of a challenge. How do we determine the usage of the term? That is, how do we interpret and theorise it, as an affirmation or as a negation of citizenship, or both? Seeking to offer an answer to these questions, the section explores the category of noncitizenship through the lens of accounts of inclusive citizenship. By accounts of inclusive citizenship, I mean the growing body of work that highlights and challenges the exclusions that accompany citizenship politics, with the aim of extending - redescribing and opening up - the practices that are considered to be citizenic (Kabeer, 2005; Marin, 2010; Soysal, 1994; Andersen and Siim, 2004; Gaventa and Tandon, 2010; Lister, 2007). While accounts of inclusive citizenship come in many forms, in this section I distinguish and focus on the three variants that I term pluralist, political, and democratic. The terms 'pluralist' and 'democratic' issue from a retrospective reading of work on citizenship. They selectively capture the 
common threads running through this body of work and bring attention to the shifts and turnings in the meaning of noncitizenship. By contrast, the term 'political' stems from the intention to politicise the experience of noncitizenship - that is characteristic of the type of work that the section focuses on.

There are three reasons why the frame of inclusive citizenship offers a fertile ground for theorising noncitizenship. First, accounts of inclusive citizenship problematise the relation between citizen and noncitizen, and in so doing, accentuate the ambivalence at the heart of the category of noncitizenship. Second, they expose the difficulty facing theorisations of noncitizenship as a distinct analytical category, namely, the reproduction of the relationship with citizenship. Third, they foreground inclusion as an inescapable dimension of theories of noncitizenship. Seeking to isolate this dimension and, thus, show the conceptual overlap between theories of noncitizenship and accounts of inclusive citizenship, the section subsumes the former under the latter; and it discusses work on noncitizenship as the political variant of accounts of inclusive citizenship. Before this, however, the section explores the pluralist variant.

The pluralist variant develops on the terrain of identity politics, particularly in work that seeks to address the challenges currently confronting multicultural and multinational democracies - such as ensuring democratic equality while respecting difference (see Kymlicka 1996, 2001; Lister, 2007). It takes issue with the formalistic and universal dimensions of citizenship and highlights issues of entry, recognition, and rights (Kymlicka, 1996, 2001; Isin and Wood, 1999; Pakulski, 1997; Parekh, 2000; Philips, 2003; Stevenson, 2003; Young, 1995, 2000). Concerned with the ways in which liberal democracies exclude, assimilate and discriminate against difference, theorists in the pluralist canon seek to renegotiate the terms and modes of membership. The term 'pluralist' derives from this renegotiation, for the primary aim here is to challenge the uniformity of citizenship by opening up and accentuating modes of membership that differ from and often challenge its dominant mould. Indeed, citizenship denotes membership on this account. It is associated with the typical Marshallian rights - civil, political, social - and it has liberal and legalistic overtones that carry over to the requisites for inclusive citizenship (see Marshall, 1950). These consist of less stringent criteria for entry into citizenship - ranging from residence to universal personhood (Soysal, 1994); formal recognition of particularity, 
the different ways one is and acts as a citizen (Young, 1995); and the expansion of formal legal rights to include (often by differentiating) excluded groups (Kymlicka, 1996, 2001; Parekh, 2000). Formal rights and rules ease the passage to citizenship. More importantly, they initiate a shift in the very norms and practices of citizenship.

To see this shift more clearly - that the second and third variants of inclusive citizenship rely on - it is important to notice the three key contributions of the pluralist account to narratives of inclusive citizenship. The first consists in its sophisticated account of exclusion. By distinguishing between outer and 'inner exclusion'i (Taylor 1999, 276) work on identity politics brings attention to the continuous interplay between citizen and noncitizen, to the back and forth movement between experiencing political life as a citizen and as a noncitizen. If the rights-holder experiences exclusion (because of her identity, lifestyle, culture or religion), then the analytical category of noncitizenship does not just emerge when there is limited (or no) access to rights, but also when there is access to citizenship. Second and closely related, the pluralist variant notably expands the realm of noncitizenship. The noncitizen is the outsider, the different, the denizen, the third-country national, the illegal immigrant, the refugee, the woman - that is, anyone mistrusted, marginalised or stigmatised by dominant norms. While this expansion subverts the divide between inside/outside which citizenship perpetuates, it does not do away with the divide itself. Citizenship remains the most important form of membership and the noncitizen, as I will explain later in the section, is only seen to strive for inclusion (even when this is conceived in differential terms).

Third, the attention to law, that is, to the range of measures necessary to alleviate exclusionary politics - ranging from multicultural policies to positive discrimination and human rights law - fosters democratic practice. This means that inclusive citizenship is not simply seen as a moral good that liberal societies aspire to, but as a distinctly democratic good that can in fact be put into practice. Therefore, the focus on the legal and liberal dimensions of political membership, pressed by the pluralist variant, opens the way for attending to practice; and, in so doing, it casts light on the everyday, political and democratic parameters of this practice. Of course, it might be more accurate to use the past tense here and take the pluralist variant as the predecessor to what I here designate as the democratic and political variants - 
especially if we consider that work on identity politics was at its height in the eighties and nineties. However, I think it is more useful to avoid a linear narrative and emphasise their interlacing. This interlacing becomes more evident when we direct attention to the work of specific theorists. Seyla Benhabib's work serves as a good example here (Benhabib, 2005, 2007, 2009).

Benhabib is deeply dissatisfied with liberal accounts of citizenship as a status. However, she neither rejects rights-based approaches to citizenship nor does she reconceptualise citizenship with the aim of making it more inclusive - at least not explicitly. Instead, she strongly defends the idea of 'citizenship of place', citing the disaggregation of citizenship rights in international legislation (Benhabib, 2005, 2007; see also Gordon-Zolov, 2010, 275); and she argues that the jurisgenerative capacity of international human rights law has the potential to 'develop new vocabularies for public claim making, by encouraging new forms of subjectivity to engage with the public sphere, and by interjecting existing relations of power with anticipations of justice to come' (Benhabib, 2009, 696). Therefore, the point here is that Benhabib turns to (international) law to ascertain the rights and, crucially, subjectivities of noncitizens. She distinguishes between rights, subjectivity and membership to the nation state and, in so doing, she prefigures the distinction that the political variant draws between citizenship as membership status and noncitizenship as emergent condition. At the same time, Benhabib's focus on democratic iterations (2009), that is, on deliberative exchanges that contest, expand, and transform existing practices of citizenship, interlaces with the emphasis that the democratic variant places on practice. Indeed, it can be argued that the reason that Benhabib's work perfectly illustrates the interlacing between the three variants of inclusive citizenship is because it combines the focus on the practice of noncitizenship (that perforates the political and democratic variants) with an account of noncitizenship as an often permanent, outside yet inside, legal and political status (pluralist and political variants). This account of noncitizenship lies at the centre of the political variant of inclusive citizenship that I now move on to examine.

In particular, the political variant encompasses ethnographic and sociological work on noncitizenship. In contrast with the other two variants that expand on the realm of noncitizenship, the political variant narrows it down to the field of migration. This 
means that the noncitizen denotes a particular form of exclusion that challenges the inside/outside boundaries of the political community. She is, for example, the long term migrant who has temporary and often precarious access to citizenship rights, or little to no access to such rights by virtue of her irregularity (De Genova and Peutz, 2010; Squire, 2010; Hepworth 2014a, 2014b). The noncitizen, so articulated, foregrounds a more nuanced relationship with citizenship than the one that we notice in the pluralist variant. For example, on some accounts, the noncitizen is expelled from the order of citizenship (see Hepworth's account of abject citizenship, 2014b); on other accounts, she oscillates between security and insecurity (see the account of precariousness developed by Goldring et al, 2009); and yet on other accounts, the noncitizen challenges the juridical world of citizenship (Nyers, 2003). Despite such understandable variations, however, this critical literature on noncitizenship agrees that far from being the mere victim of state-policies, the noncitizen exposes, disrupts, and exceeds such policies. The type of negotiations that noncitizen actions elicit, such as unauthorised cross-border mobility, question the meaning of legal citizenship and also, crucially, enact citizenship (Hepworth, 2014a). That is, they express a form of embodied and emergent citizenship that directly undermines the legal status of (non)citizenship (Hepworth, 2014a, 2014b; Mezzadra and Neilson, 2012).

This emphasis on citizenship enactment constitutes the most important contribution of this variant to accounts of inclusive citizenship. First, it shows that political agency, far from being confined to citizens, attaches also to noncitizens. Noncitizens contest and challenge the inside-outside distinction that the state system perpetuates and, by so doing, they politicise, claim and embody, a type of citizenship that exists alongside standard accounts. Second, the emphasis is placed upon political agency, showing that far from seeking to open up or modify the legal order of citizenship, theorists of noncitizenship interrogate and, notably, defy the distinction between legality and illegality pressed by vocabularies of citizenship. Understood as a permanent condition, noncitizenship exceeds and subverts the limits set on politicisation by legal rules. This primacy given to politics over law has a noteworthy implication for accounts of inclusive citizenship. Although inclusion into citizenship looses the legal overtones that it carries in the pluralist variant, it finesses a sociopolitical process that at once augments and reinstates the citizenic logic of politics. While noncitizens politicise against the legal rules of citizenship, their politicisations, 
anchored as they are in the language of citizenship, precipitate nothing less but the expansion of its politics - or, at least, the expansion of what is considered as citizen politics. Therefore, the third, related, contribution to accounts of inclusive citizenship is the move away from the pluralist variant's focus on membership to highlight the limits of (non)citizenship as a legal status. By identifying ways of being a citizen outside of and beyond the legal parameters of citizenship, it paves the way for the democratic variant that probes deeper into the conditions of this emergent, disruptive and political noncitizenship.

In particular, the first thing to notice about the democratic variant is that it breaks further away from accounts of citizenship as legal status (political variant) and membership (pluralist variant). Instead, it focuses on the participatory dimension of citizenship and draws attention to political practices that challenge and transgress conventional ways of contributing to citizen politics - such as, for example, voting (Mohanty and Tandon, 2006; Pateman, 2012; Cornwall and Coelho, 2006; Desforges, Jones and Woods, 2005; Kopf, 2010). In line, therefore, with the political variant, the democratic one accentuates the focus on political practice - on the many sites and scenes of citizenship (Isin, 2008). However, in contrast with the political variant, it does neither limit this practice to migrants nor to politicisation. Instead, the democratic variant opens up noncitizen practice to other actors (such as the poor as we will shortly see); and it ties politicisation with democratisation - that is, with other ways of experiencing and practicing democracy. Thus the first distinctive contribution of this variant to narratives of inclusive citizenship issues from its expanded account of practice.

Two theoretical ideas underpin this account: citizenship practice as an everyday, lived, experience and citizenship practice as participation/deliberation in dynamics of governing. Ruth Lister explains that lived experiences of citizenship consist of renegotiations of rights and responsibilities in the everyday and not just in moments conventionally considered to be democratic - such as protests or elections (Lister, 2007). Lived citizenship, as renegotiation, emerges in the workplace, the private realm and/or the domain of the intimate (see Cohen, 2009). Of course, the citizen qualities of such everyday renegotiations of rights, duties and obligations might be critically questioned. However, to confine thinking to such criticisms would be to 
miss the emphasis on the lived and experienced. This emphasis, as Lister highlights, draws attention to the system, to those enabling/disabling conditions (material and cultural) that carry implications for the everyday life of (non)citizens (Lister, 2007). The participatory form that citizenship action takes in the democratic variant further accentuates this focus on the systemic conditions that often hinder citizen involvement and input to ways of governing. By drawing attention to persistent inequalities of wealth, position, societal status, skills and abilities, and the way these undermine democratic life, the deliberative perspective ${ }^{\mathrm{ii}}$ has developed a large body of empirical work that tackles conditions of unequal participation (see Pateman, 2012; De Souza Santos, 2006). Citizen juries, panels, participatory budgeting, all constitute attempts to secure participation from marginalised groups of citizens unable to have a say about the way they are governed - and this is especially the case when we look at deliberative/participatory initiatives in the Global South (see Thompson and Tapscott, 2010; Kopf, 2010).

Therefore, the important point here is that with this variant we have a stronger emphasis on the conditions for exercising citizenship - rather than the measures for securing inclusive citizenship (that we find in the pluralist variant). With this emphasis an additional dimension of noncitizenship comes to the fore. Noncitizens are not only those excluded, marginalised, stigmatised or demonised by the formal and uniform politics of citizenship; but also the poor, the unskilled, the exploited or the unequal (a more refined category than the excluded). Noncitizens, in other words, are the non-actors - those who lack the resources to act and, thus, miss out on the benefits of citizenship in their everyday life where meaningful access to citizenship matters the most.

This brings us to the second, perhaps more crucial, contribution of the democratic variant to narratives of inclusive citizenship: the citizenisation of noncitizens. By citizenisation $^{\mathrm{iii}}$, I mean processes of citizen formation - that is processes of citizenbecoming or citizen-constitution as these arise in particular (though various) locales, as a result of specific enabling conditions (or their lack thereof). ${ }^{\text {iv }}$ The primacy given to practice by the democratic variant encases this promise of citizenisation and, in so doing, it gives the idea of inclusionary citizenship its most radical 'twist': everyone can become a citizen, even though not anyone is a citizen (see Tully 2008b, 99). By 
engaging in practices that converse with the institutional politics of the given citizenship order, contesting, or going against these, political subjects become citizens. This insight into processes of citizenisation evades the divide between the citizen and the noncitizen, democracy (citizenship) and politics (noncitizenship) that is still folded into the political variant with its limited focus on the migrant. So long as someone acts with the aim of drawing attention to injustice, inequality, subordination or marginalisation, one acts as, and thus is, a citizen. Whether the actor has access to rights is irrelevant. Instead, what is relevant is that the citizen emerges out of this struggle for democracy. That is why she is now seen as a democratic actor, and not merely as a political subject; because she seeks such distinctly democratic idea(l)s as equality, justice, recognition, inclusion. At the same time, the very focus on citizenbecoming, rather than citizen-being, inverts the meaning of inclusive citizenship (Isin, 2008). It is not the inclusion of the 'other' that makes citizenship inclusive, but the reverse; it is the expansive account of democracy that invites the inclusion of the noncitizen into the world of citizenship. It is noteworthy, then, that both citizenship and inclusion, albeit their reconception, remain firmly at the centre of the democratic variant, much like in the pluralist and political ones.

This is where, I now argue, the limits of all three variants lie. By retaining the focus on citizenship and inclusion, the pluralist, political and democratic variants end up reproducing, if not consolidating, the binary between citizenship and noncitizenship. Of course, the underlying argument here is not that we need to turn away from the order of citizenship, dismissing its politics, that are, after all, the last stronghold of state sovereignty and, as such, the subject in need of continuous interrogation; nor does the argument intend to gloss over or undermine demands and struggles for inclusion. Rather, the point here is that it is one thing to recognise the reality of citizenship and its exclusionary implications for those who are not part of it, and quite another to see citizenship as the highest, most valuable practice, the benchmark for evaluating - acknowledging and noticing -the demands raised by a variety of groups. The second assumption, which is exactly what I find limiting here, perforates all three variants. In so doing, it reproduces, through the back door, the very binary between inside and outside that the pluralist, political, and democratic variants problematise. Indeed, whether we view the noncitizen as the subject who seeks to be recognised and included in the liberal order of citizenship through changes in law and access to rights 
(pluralist variant); or as the migrant who enacts citizenship (political variant); or even as the non-actor who citizenizes through spontaneous and/or deliberative practice (democratic variant); it is difficult to escape the conclusion that the noncitizen is the inevitable victim of the state system that occasionally subjectifies to seek inclusion in that system, the highest order of citizenship.

To explicate the point further, the problem with this conclusion is not victimhood per se - that as we have seen the political variant does a good job challenging - but the primacy given to citizen-isation, that potentially undermines claims and demands for a better life in the here and now. By pointing to the larger scripts of citizenship that implicate institutions, state actors and societal attitudes, citizenship-construed demands displace the particular by the general - on the assumption that references to the general of citizenship give weight to particular claims to citizenship. However, do we need the lens of citizenship to respond to and address injustice, exclusion, discrimination? I will return to this question in the next section. Here suffice to notice that by taking citizenship as the benchmark for all political practice, the pluralist, political, and democratic variants reinstate the binary citizen/noncitizen that they seek to disturb and unsettle.

The second limit of the pluralist, political, and democratic variants is closely related to the first one. It concerns the interrelation between citizenship and noncitizenship that runs through the three variants of inclusive citizenship. By tying noncitizenship with citizenship, that is, by tying the being of noncitizens with that of the citizens, all three variants cancel out noncitizenship as an analytical category. Noncitizenship becomes reduced to a journey to citizenship and, as such, as a journey, it looses meaning and force. At the same time, a retrospective reading arises that assimilates struggles for new kinds of politics into the canonical narrative of modern citizenship. James Tully is particularly attuned to this danger when he points out that even when the rights of noncitizens are institutionalised and their conditions bettered, this betterment 'is redescribed retrospectively as a stage in the development of modern citizenship and incorporated within its framework' (Tully, 2014, 18-19). The danger, therefore, that Tully's point alerts us to is that the very category of noncitizenship might inadvertently undermine struggles for another politics, by limiting these to 
struggles for and against citizenship. However, as the next section shows, it is possible to take such struggles seriously without falling back on the vocabulary of noncitizenship. To this end, the next section explores the idea of politicisation and contrasts its analytical force with that of the category of noncitizenship.

\section{Rethinking Noncitizenship}

The previous section developed two arguments. The first argument was that the analytical category of noncitizenship is closely entangled not just with citizenship by way of antithesis, but with accounts of inclusive citizenship in particular. By tracing the shifts and turnings in the concept of noncitizenship within such accounts, the previous section highlighted the floating nature of the concept that the pluralist, political and democratic variants exploit to the full. Three particular moments in the account of these variants are noteworthy. The first is that noncitizenship significantly expands and blurs with citizenship - once exclusion, marginalisation and stigmatisation are seen to be experienced by anyone whose identity does not conform to dominant norms. The second noteworthy moment in discussions of inclusion is that noncitizenship becomes synonymous with non-action - in the absence of enabling resources (material and cultural). Finally, processes of citizenisation - or citizen enactment in the vocabulary of the political variant - displace the analytical and legal category of noncitizenship. Although access to rights still formally distinguishes citizens from noncitizens, political agency and practice that is common to both categories, ensures that noncitizens become citizens when they politicise and engage in practices that challenge the exclusionary politics of citizenship. Does this indicate that noncitizenship is a superfluous category? The second argument of the previous section was that the very persistence of the binary between citizen/noncitizen undermines the analytical force of the category of noncitizenship.

Of course, it might be objected that there are examples of noncitizenship that point to the opposite direction - particularly when noncitizenship is taken to denote partial access to the rights of citizenship in the state (or region) one resides but is not a full citizen of - as a result of multilevel governance (for a critical account of multi-level citizenship see Bauböck and Guiraudon, 2009). Denizenship, for example, as 
exemplified in the case of European citizens who "carry their citizenship abroad and exercise it from outside' has often been construed as a transgressive category that undermines, rather than reinforces, the citizen/noncitizen binary (Bauböck and Guiraudon, 2009, 440). However, it is also a more limited category in that it simply taps into and expands rights-based accounts of citizenship, leaving the exclusivity of the status of citizenship either untouched - as is the case with the pluralist variant - or only partly questioned (when the focus is on the national dimension of citizenship). Nevertheless, cases of multi-level citizenship raise the question: is it possible to leave the citizen/noncitizen binary aside and see some strengths in noncitizenship as an analytical category?

On the one hand, it can be argued that noncitizenship is a necessary category, because it captures the excess of politics. So long as there are citizens, there will be noncitizens, that is, a surplus or excess of politics - a political difference - that either does not conform to the given citizenship order and/or challenges the dominant norms of this order (see Honig, 1993). At the same time, it can be argued that noncitizenship is not just a necessary category, but also a useful one. It alerts us to the exclusions, inequalities, marginalisations and naturalisations that accompany citizenship politics. Therefore, by continuously interrogating who the noncitizens are, we keep an eye on democratic exclusions and, in so doing, we ward off - or at least we attempt to ward off - closures and exclusions. On the other hand, however, it can also be argued that we do not need the category of noncitizenship to notice and attend to democratic closures and exclusions. After all, instances of injustice and inequality can be recognised without resorting to the vocabulary of noncitizenship, as any newspaper reader will immediately confirm. More than that, terms such as 'inequality', 'destitution', 'injustice' are more powerful than 'noncitizenship' to capturing attention and stirring action.

Of course, it can be argued that noncitizenship foregrounds questions of democracy. By enquiring into democratic exclusions - the ways in which liberal democracies fail to admit, integrate, and support 'difference' or 'otherness' - the concept of noncitizenship forces us to continuously assess and evaluate the ways in which democratic idea(1)s translate into democratic practice. But, still, do we need the category of noncitizenship to evaluate the quality of democratic life? As the previous 
section argued there is something disturbing in the idea - in vogue today - that all politics be read as citizenship politics to gain democratic ground. The assumption that informs this idea, that citizenship is the most valuable practice, the door to a better politics, tends not just to underplay the particularity of the given demand and struggle, but also to undermine the very plurality of politics. To be sure, it is vital that struggles against exclusion, inequality and injustice gain democratic ground (and are translated into measures that reflect these gains). However, it is questionable whether they need the lens of noncitizenship to do so. Politicisation can do the same work. The remaining of this section explains why. It starts by identifying the overlap between politicisation and noncitizenship; and it moves on to discuss the two components of the politicising process that make it a better alternative to noncitizenship.

By politicisation, I mean a process of political subjectification where subjects excluded from the institutional world direct attention to their situation and, through public action, bring visibility to the inequalities and injustices permeating this world (see Rancière, 1999). Politicisation, therefore, like the category of noncitizenship, confronts relations of power and inequality, presupposes agency and involves practice. In particular, subjects who politicise seek to challenge the established order. They bring into view the power dynamics behind this order - its closures, injustices and inequalities; and, in so doing, they openly unsettle these. Although it can be credibly objected here that the noncitizens (the poor, excluded, marginalised) are not always in a position to politicise and confront the power order - and this alone reveals the force of noncitizenship as an analytical category; it can be argued that noncitizenship, much like the concept of politicisation in this sense, promises something more than a comprehensive exposé of the inequalities perforating a given power order. It promises citizenisation. Citizenisation involves political subjectification - as is the case with politicisation. At the same time, politicisation, like citizenisation or noncitizenship for that matter, gains momentum through references to a variety of scripts, from 'justice' and 'equality' to even 'citizenship' and this means that either sections of society politicise to give visibility to the position/demands of those who cannot, or the excluded and marginalised subjectify and politicise. Therefore, the point here is that there is significant overlap between the concepts of politicisation and noncitizenship when it comes to matters of subjectification and counter-power. There is also overlap with respect to practice. 
Politicisation is practice, for subjects politicise against or for something- for example, by setting up a sit-in, a protest, an occupation etc. In fact, political protests (against the state) can be seen as exemplary moments of politicisation, where the binary citizen/noncitizen becomes redundant.

In particular, what makes protests exemplary moments of politicisation (at least in the way I use the term here) is their public nature - the publicity, connection, openness and generality that they encase. Protests publicise exclusion X; they make it visible. They are public events and this means that they both reach out to the public and draw in (the support of) the public - broadly understood. At the same time, public protests are sites of assembling. They gather the people together and, in this gathering, it makes little difference who is the citizen and who is not, or who initiated the protest and who did not. What matters is that protests remain open and, as a result of this openness, demands flesh out, intermesh and expand. More than that, the openness of the protests compounded by the indeterminacy of the subject 'people' as a democratic actor has the additional effect of drawing sharper attention to the political demand or claim eliciting the protest. This is where, in the end, the greatest difference between the concepts of politicisation and noncitizenship lies: in their telos. Whereas the telos of politicisation, say in the case of public protests to stay with the same example, is to have the particular (series of) demands or claims met in the here and now - thus it has a rather limited, provisional, target that does not always or necessarily coincide with an expansion of rights; the telos of the category of noncitizenship is often, inadvertently, citizenship - and, this implicitly enfolds the aspiration to expand on existing rights.

By defending, therefore, politicisation I move a step further from the critical literature that sees the politicisations of noncitizens as intrinsic to the enactment of citizenship (Isin, 2008; Hepworth 2014a and 2014b). More than that, as William Walters warns, 'we should not overlook those moments when political interventions refuse to make strong claims in the name of citizenship ... because subjects explicitly reject the rights, responsibilities and commitments that are associated with the citizen, or out of preference for other identities' (2008, 185, 193). Attending to such moments of struggle, that Walters refers to as 'acts of demonstration', opens the way for noticing 
new possibilities that arise in the course of such struggles $(2008,194)$. To be sure, what Walters calls 'acts of demonstration' is what I here refer to as politicisation, for acts of demonstration 'occur when an injustice is revealed, a relationship of power is contested, or a particular wrong is protested, but when the identity of the subjects, at the heart of the protest is left relatively open' (Walters, 2008, 194). But there is a difference. Whereas Walters suggests that 'acts of demonstration' supplement political acts of noncitizenship, I suggest that politicisations blur with acts of noncitizenship.

There are two reasons behind this suggestion. The first reason is that politicisations that do not tie the identity of the political subject with that of the citizen, promote a stronger conception of agency. This is particularly important for those subjects who are noncitizens for their entire life, such as for example Palestinian refugees in Lebanon and/or the occupied territories who do not struggle for either Lebanese or Israeli citizenship (Salih, 2013; Allegra, 2009) . However, they do struggle to improve and renegotiate the conditions of their life in the here and now. This is a continuous and ordinary struggle, neither exceptional nor just disruptive as the literature on noncitizenship would have it (Hepworth, 2014a and 2014b). In this ongoing struggle, agency dissociates from identity (Salih, 2013). That is, political agency exceeds the identity of (non)citizenship and, it is important that work on citizenship studies acknowledges and recognises the indeterminacy of this agency. At the same time, politicisations that do not tie the identity of the subject with that of the citizen are potentially more effective in drawing attention to the exclusions and injustices of citizenship. Construed as political acts, they open up possibilities that resist the normalisations, naturalisations and framings that accompany references to citizenship. Thus, the following question arises: if politicisation is a potentially more effective target specific - process of interrogating exclusions, then is it possible to give it some form beyond the setting of the public protest? In other words, is it possible to identify some of the components that contribute to its weight as a process?

James Tully gives us a good idea of one of these components. In his discussion of civic freedom, he offers sufficient cues to enable us to envision politicisation outside the setting of the public protest (2008a and 2008b). In particular, practices of civic freedom consist, according to Tully, of the freedom to question, renegotiate and, as a 
result, renew the terms of the political game. For example, if there is, say, inequality and exploitation in the work place, the moment that groups of unequal/exploited workers question (from their different positions and for their different reasons), these relations of inequality, practices of civic freedom come into play. Indeed, practices of civic freedom, according to Tully, arise together with practices of governance understood in an expansive sense as relations of control (see Tully, 2008a, 24-25). In a typical Foucauldian way, therefore, what Tully tells us here, is that wherever there is power, closure, exclusion, there is resistance. There is the possibility to interrogate power and domination, confront and change it. Now, what I find useful in the idea of 'practices of civic freedom' is, first, that they arise wherever there is domination, control, exclusion - thus, the concept attends to the omnipresence of power, exclusion, inequality. Second, practices of civic freedom appear to have the same effect as noncitizenship, that is, they challenge exclusions without, however, pinning down the political subject behind them. Third, and perhaps more importantly, practices of civic freedom are neither necessarily nor exclusively aimed at introducing a change in the order of citizenship (by expanding, for example, its rights). They are just that: practices of freedom against relations of control, domination or subordination. Thus, practices of civic freedom can be seen as the politicised moment par excellence. What is missing from this moment is the focus on demands/claims that I previously tied with the idea of politicisation.

To attend to this moment, and thus explore the second component of politicisation, we need to move a step further from Tully, and return to the idea of claims-making that I have already discussed in passing. The aim here is to make the connection between claims-making and politicisation explicit. Michael Saward (2006) talks about claims. Claims are for Saward performative, creative and representative. They can be taken up by all kinds of actors and they produce subjects, objects and audiences. For Saward, therefore, it is the claim itself that has productive effects (produces representation), not the subject who formulates the claim. Or, as he puts it: 'what exists are claims and their receptions' (Saward, 2006, 306). Indeed, by highlighting the constituting and everyday dimension of claims-making, Saward opens interesting lines of enquiry into its role in interrogating exclusive politics. To see these, we need to briefly look at the nature of claims-making. In particular, claims-making puts emphasis on the claim itself - since it is the specificity of the claim that constitutes 
political projects. At the same time, the claim does more than facilitate the expression of a grievance or issue. Claims-making seeks to re-formulate and, indeed, re-negotiate the given unequal power distribution - this is why it is also relevant to long-term noncitizens. Claims open the way to re-negotiation because they are, first, necessarily narrower, target-specific, and more limited than citizenisations are. Second, claims to someone or something establish a relation of interdependence between the side that produces the given claim (the noncitizens) and the side that responds to the claim (the state). Third, and perhaps more importantly, claims already envelop alternatives to the existing order, since this is precisely what defines and distinguishes them as claims, the requests or demands they encase.

Indeed, the very possibility of transforming the world of citizenship politics, by challenging and exposing the exclusions and injustices that define it in the here and now, is one dimension that for the time being escapes attempts to theoretically refine the category of noncitizenship. One reason for this is perhaps innate to the category of noncitizenship. Noncitizenship captures the journey to citizenship, the quest to be included in citizenship. It is a telic process and its telos, as I have been arguing throughout the paper, constitutes its key limit. Politicisation, by contrast, evades this limit because it draws attention to process, subjectification, agency and claims-making. Although the binary citizen/noncitizen can inform the politicizing process, it does not define it. This makes politicisation a potentially richer category than noncitizenship for theorising contentious politics over and against set frames of citizenship. Of course, the emphasis that I here place on politicisation does not imply that we altogether give up on the category of noncitizenship, for noncitizenship does not necessarily preclude politicisation. As the section showed, there is considerable overlap between the two concepts. However, what my emphasis on politicisation does imply is that we need to start by problematising the binary citizen/noncitizen that taps into attempts to theorise noncitizenship. Although this is a difficult task, the undecidability of the prefix non invites attempts, such as this one, to travel the road away from citizenship.

\section{Conclusion}

The paper explored the implications of the case for noncitizenship as a distinct analytical category. By tracing the nature of the concept in trajectories of inclusive 
citizenship, it argued that its key limit issues precisely from its entanglement with citizenship and citizenisation. To support this argument, the paper distinguished between a pluralist, political and democratic variant in accounts of inclusive citizenship; and it showed how they end up reinstating the very binary citizen/noncitizen that they intend to interrogate. Seeking to overcome this limitation, the paper discussed the idea of politicisation and contrasted its empowering potential with that of noncitizenship. Do we need, in the end, the category of noncitizenship to acknowledge and challenge relations of exclusion, power, inequality, injustice and discrimination? The paper answered this question by suggesting that to consolidate the analytical force of the category of noncitizenship we need to start with the difficult task of attenuating its relationship with citizenship.

\section{Endnotes:}

${ }^{\mathrm{i}}$ In contrast with outer exclusion that captures the reluctance to either admit outsiders into citizenship or trust them as co-citizens; 'inner exclusion' designates the subordination of other ways of being a citizen into the dominant mould of citizenship. This dimension of exclusionary politics has been heavily criticized by the literature on gender politics (Taylor, 1999; see also Young, 1995 and 2000; Lister 2003). ii Here it is important to note that I use the terms deliberation and participation interchangeably. For the opposite view see Mutz, 2006.

iii I borrow the term 'citizenisation' from the work of James Tully (2008a; 2008b).

${ }^{i v}$ Engin Isin (2008) gives the most sophisticated account of such processes of citizenisation when he distinguishes between acts of citizenship (that involve disruption, rupture, and a break with an order) and citizenship action (that envelops routine, habit and order).

\section{Bibliography}

Agamben, G. 1998. Homo Sacer: Sovereign Power and Bare Life. Stanford, CA: Stanford University Press.

Allegra, M. 2009. "Citizenship in Palestine: A Fractured Territory". Citizenship Studies 13(6):553-573.

Andersen, J., and Siim, B. (eds). 2004. The Politics of Inclusion and Empowerment: Gender, Class and Citizenship. Houndmills: Palgrave Macmillan.

Arendt, H. 1968. "The Decline of the Nation State and the End of the Rights of Man". Chapter 9 in The Origins of Totalitarianism. New York: Harcourt Inc.

Bauböck, R. and Guiraudon, V. 2009. "Introduction: Realignments of Citizenship. Reassessing Rights in the Age of Plural Memberships and Multi-level Governance". Citizenship Studies 13(5):439-450. 
Benhabib, S. 2009. "Claiming Rights Across Borders: International Human Rights and Democratic Sovereignty". American Political Science Review 103(4): 691-704.

Benhabib, S. 2007. "Twilight of Sovereignty or the Emergence of Cosmopolitan Norms? Rethinking Citizenship in Volatile Times". Citizenship Studies 11(1):1936.

Benhabib, S. 2005. “Disaggregation of Citizenship Rights”. Parallax 11(1): 10-18.

Cohen, E. 2009. Semi-Citizenship in Democratic Politics. Cambridge: Cambridge University Press.

Cornwall, A. and Coelho, V.S. 2006. Spaces for Change? The Politics of Citizen Participation in New Democratic Arenas. London: Zed Books.

De Genova, N. and Peutz, N. (eds.). 2010. The Deportation Regime: Sovereignty, Space and the Freedom of Movement. Durham: Duke University Press.

De Souza Santos, B. 2006. Democratizing Democracy: Reinventing Social Emancipation. London: Verso.

Desforges, L., Jones, R., and Woods, M. 2005. "New Geographies of Citizenship". Citizenship Studies 9(5):439-451.

Gaventa, J., and Tandon, J. 2010. Globalising Citizens: New Dynamics of Inclusion and Exclusion. London: Zed.

Goldring, L., Berinstein, C. and Bernhard, J.K. 2009. "Institutionalizing Precarious Migratory Status in Canada", Citizenship Studies 13(3):239-265.

Gordon-Zolov, T. 2010. "A Conversation with Seyla Benhabib and Judith Resnik". Women's Studies Quarterly 38(1 \&2): 271-286.

Hepworth, K. 2014a. "Encounters with the Clandestino/a and the Nomad: The Emplaced and Embodied Constitution of Non-Citizenship." Citizenship Studies 18(1): $1-14$.

Hepworth, K. 2014b. "Topologies of Citizenship". In Routledge Handbook of Global Citizenship Studies, edited by Engin F. Isin and Peter Nyers, 110-118. Abingdon:

Routledge.

Honig, B. 1993. Political Theory and the Displacement of Politics. Ithaca: Cornell University Press.

Isin, E. 2008. "Theorising Acts of Citizenship". In Acts of Citizenship, edited by Engin F. Isin and Greg Nielsen, 15-43. London: Zed Books.

Isin, E. F., and Wood, P.K. 1999. Citizenship and Identity. London: Sage.

Kabeer, N. (ed.). 2005. Inclusive Citizenship. London: Sage.

Kopf, B. 2010. “The Geography of Participation”. Third World Quarterly.

Kymlicka, W. 2001. Politics in the Vernacular: Nationalism, Multiculturalism and Citizenship. Oxford: Oxford University Press.

Kymlicka, W. 1996. Multicultural Citizenship: A Liberal Theory of Minority Rights. Oxford: Clarendon Press. 
Lister, R. 2007. "Inclusive Citizenship: Realizing the Potential”. Citizenship Studies 11(1): 49-61.

Lister, R. 2003. Citizenship: Feminist Perspectives. Basingstoke: Palgrave Macmillan.

Marin, R. 2010. Immigration as a Democratic Challenge: Citizenship and Inclusion in Germany and the United States. Cambridge: Cambridge University Press.

Marshall, T.H. 1950. Citizenship and Social Class. Cambridge: Cambridge University Press.

Mezzadra, S. and Neilson, B. 2012. "Between Inclusion and Exclusion: On the Topology of Global Space and Borders". Theory, Culture and Society 29(4-5):58-75.

Mohanty, R., and Tandon, R. (eds). 2006. Participatory Citizenship: Identity, Exclusion, Inclusion. London: Sage.

Mutz, D. 2006. Hearing the Other Side: Deliberative Versus Participatory Democracy. Cambridge: Cambridge University Press.

Nyers, P. 2003. "Abject Cosmopolitanism: The Politics of Protection in the AntiDeportation Movement". Third World Quarterly 24(6): 1069-1093.

Pakulski, J. 1997. “Cultural Citizenship”. Citizenship Studies 1(1):73-86.

Parekh, B. 2000. Rethinking Multiculturalism: Cultural Diversity and Political Theory. Houndmills: Macmillan Press.

Pateman, C. 2012. "Participatory Democracy Revisited". Perspectives on Politics 10(1): 7-19.

Phillips, A. 2003. "Recognition and the Struggle for Political Voice". In Recognition Struggles and Social Movements, edited by Barbara Hobson, 263-273. Cambridge: Cambridge University Press.

Rancière, J. 1999. Disagreement: Politics and Philosophy, translated by J. Rose. Minneapolis, MN: University of Minnesota Press.

Salih, R. 2013. "From Bare Lives to Political Agents: Palestinian Refugees as AvantGarde". Refugee Survey Quarterly 32(2): 66-91.

Saward, Michael. 2006. "The Representative Claim," Contemporary Political Theory 5: 297-318.

Squire, V. (ed.). 2010. The Contested Politics of Mobility: Borderzones and Irregularity. Abingdon: Routledge.

Soysal, Y.N. 1994. Limits of Citizenship: Migrants and Postnational Membership in Europe. Chicago: University of Chicago Press.

Stevenson, N. 2003. Cultural Citizenship. Buckingham: Open University Press.

Thompson, L., and Tapscott, C. (eds). 2010. Citizenship and Social Movements: Perspectives from the Global South. London: Zed. 
Taylor, C. 1999. "Democratic Exclusion (and Its Remedies?)". In Citizenship, Diversity and Pluralism: Canadian and Comparative Perspectives, 265-286. Montreal: McGill-Queen's University Press.

Tully, J. 2014. On Global Citizenship: James Tully in Dialogue. London: Bloomsbury Publishing.

Tully, J. 2008a. Public Philosophy in a New Key. Volume I, Democracy and Civic Freedom. Cambridge: Cambridge University Press.

Tully, J. 2008b. Public Philosophy in a New Key. Volume II, Imperialism and Civic Freedom. Cambridge: Cambridge University Press.

Walters, W. 2008. "Acts of Demonstration: Mapping the Territory of (Non-) Citizenship". In Acts of Citizenship, edited by Engin F. Isin and Greg M. Nielsen, 182-206. London: Zed Books.

Young, IM. 2000. Inclusion and Democracy. Oxford: Oxford University Press.

Young, IM. 1995. "Polity and Group Difference: A Critique of the Ideal of Universal Citizenship". In Theorizing Citizenship, edited by Ronald Beiner, 175-208. Albany: State University of New York Press. 